\title{
Growth Performance of Arsi, Borana, Harar and HF-Crossbred Bulls Finished under Similar Feeding Condition
}

\author{
Ahmedin Abdurehman Musa1, Yesihak Yusuf Mummed2, Mohammed Yusuf Kurtu², \\ Melese Temesgen ${ }^{3}$, Travis Gene 0'Quinn', Umer Seid Geletu' \\ ${ }^{1}$ Department of Animal Science, College of Agriculture, Oda Bultum University, Chiro, Ethiopia \\ ${ }^{2}$ School of Animal and Range Sciences, College of Agriculture and Environmental Sciences, Haramaya University, \\ Haramaya, Ethiopia \\ ${ }^{3}$ Department of Food Science, Institute of Technology, Haramaya University, Haramaya, Ethiopia \\ ${ }^{4}$ Department of Animal Sciences and Industry, Kansas State University, Manhattan, USA \\ Email: ahmedin133@gmail.com
}

How to cite this paper: Musa, A.A., Mummed, Y.Y., Kurtu, M.Y., Temesgen, M., O’Quinn, T.G. and Geletu, U.S. (2022) Growth Performance of Arsi, Borana, Harar and HF-Crossbred Bulls Finished under Similar Feeding Condition. Open Journal of Animal Sciences, 12, 171-191.

https://doi.org/10.4236/ojas.2022.122013

Received: September 18, 2021

Accepted: March 5, 2022

Published: March 8, 2022

Copyright (c) 2022 by author(s) and Scientific Research Publishing Inc. This work is licensed under the Creative Commons Attribution International License (CC BY 4.0).

http://creativecommons.org/licenses/by/4.0/

\begin{abstract}
The study was conducted to evaluate the fattening performance of Arsi, Borana, Harar and Holstein Friesian crossbred bulls finished under a similar feeding condition at the beef farm in Haramaya University. The average daily weight gain of the four breeds ranges from 0.49 to $0.71 \mathrm{~kg}$. Feed conversion efficiency also ranges from $0.11-0.15$. Simple linear regression models were used to explore the relationship between live body weight change and change in body condition score as well as seven linear body measurements for all age groups. An average change for a unite of body condition score was equivalent to 20.3, 20.61, 22.42 and $27.78 \mathrm{~kg}$ for Borana, Arsi, Harar and Holstein Friesian crossbred bulls respectively. Body condition score was significantly influenced by breeds. There was a significant breed by age interaction effect on the initial body condition score of the four breeds. There was a significant and positive strong association between change in body weight and body condition score. There was a significant and strong correlation between change in body weight and change in Total topline, neck length, heart girth, flank circumference and rump length having correlation coefficients ranges from 0.57 to 0.97. A higher net profit of 7380.47 ETB per head was recorded by Borana bulls followed by Harar bulls, Arsi and Holstein Friesian crossbred with net profit of 5406.86, 5193.29 and 3384.98 ETB per head respectively. Borana bulls are more superior in weight gain and net profit. Bodyweight change could be predicted based on body condition score change during the fattening period.
\end{abstract}




\section{Keywords}

Weight Gain, Body Condition Score, Change in Linear Body Measurement

\section{Introduction}

The total cattle population for Ethiopia is estimated to be about 59.45 million. The majority (98.2\%) of the total cattle in the country are local breeds. The remaining are hybrid and exotic breeds that accounted for about 1.62 percent and 0.18 percent, respectively. Regarding age groups, the majority of the cattle population (that is about $62.95 \%$ ) was in 3 to 10 years and $16.75 \%$ is 1 to 3 years. The remaining $2.25 \%$ was 10 and above years old [1].

In Ethiopia, cattle production plays an important role in the economies of the farmers and the country at large. [2] reported that cattle contribute $40 \%$ of the annual agricultural output and $15 \%$ of the total gross domestic product. There are 33 recognized indigenous cattle breeds in Ethiopia [3]. Because of its multi-purpose role, farmers have been used for milk, beef, draft power, farmyard manure and source of cash income in the country [4]. So, therefore, it has been evident that those diversified cattle breeds in all diversified agro-ecology of the country has good market and brings superior prices both at domestic and foreign markets. Such a scenario created an opportunity for small-scale cattle fattening systems in different parts of the country. Therefore, Cattle fattening has gained a reputation as an important business project of the livestock industry in Ethiopia [5]. This is special in the eastern part of the country in general and Hararghe highlands in particular [6].

Crossbreeding work in Ethiopia was initiated in the early 1950s. Following this initiation, several governmental and non-governmental institutions have worked on the development of the dairy sector [7]. This resulted improvement in milk production as well as surplus crossed bulls' availability in different parts of the country. However, lack of disposal mechanism for surplus male calves at dairy farm level has been reported as one of the main constraints in improving the dairy farm profitability [8]. The importance of dairy beef to minimize the problem of continuous supply of young bulls to the market was reported in different studies [9] [10] [11].

Animal feed both in terms of quantity and quality is a major bottleneck for livestock production in Ethiopia. Currently, with the rapid increase of human population and increasing demand for food, grazing lands are progressively shrinking by being converted to arable lands, and are restricted to areas that have little value [12]. It is clear that feed resource utilization [13]; fattening and marketing of cattle are undeveloped in different parts of the country [14]. Furthermore, developing economic feeding system that enhance the existing traditional production and emerging private business is among timely interventions required to increase production and productivity of beef cattle [15] and thereby achievement to growing demand for meat and also to the country's plan of increasing meat 
export, by encouraging small scale beef fatteners based on scientific evidences. Most cattle supplied to market from pastoral, agro-pastoral and mixed crop livestock production were reported poor in their meat quality [10] [11]. Giving due emphasis on economically feasible concentrate supplementation is important in the fattening systems.

Environmental condition during fattening period, type and amount of feed, pre-fattening condition of cattle and feedlot management determine the length of fattening period. Therefore, scarcity of feed, animal in poor condition before fattening and improper management prolong the finishing period. Longer fattening periods reduces profit realized from cattle finishing (Ebrahim et al., 2004).

Arsi, Harar and Borana bulls are also among the 33 recognized indigenous cattle breeds in the country. Their fattening performance has be studied and different results were reported by different scholars for example [7] [16] [17] [18] for Borana bulls, [8] [19] for HF-Crossbred with Borana, Barca and Horro breed respectively, [20] for Arsi bulls, [21] for Harar bulls. As result of these works differ in time and space under different feeding condition; the performance of these breeds under similar fattening conditions were not studied before. Therefore, this study was conducted to evaluate the growth performance of Arsi, Borana, Harar and HF-Crossbred bulls finished under similar feeding condition.

\section{Materials and Methods}

\subsection{Description of the Study Area}

The study was conducted at Haramaya University beef fattening unit. It is located at $9.0^{\circ} \mathrm{N}$ latitude and $42.0^{\circ} \mathrm{E}$ longitude at an altitude of $1980 \mathrm{~m}$ above sea level and $515 \mathrm{~km}$ east of Addis Ababa, Ethiopia. The area receives annual average rainfall of $790 \mathrm{~mm}$ and annual mean temperature of $16^{\circ} \mathrm{C}$.

\subsection{Animal Management and Experimental Design}

A total of 24 intact bulls from Arsi, Borana, Harar breeds and Holstein Frisian cross were grouped into two age groups ( 2 - 3 years and $4-5$ years) were used in this experiment at the Beef Farm of Haramaya University using completely randomized design as shown in Table 1.

The bulls were purchased from Kofele local market (Arsi breed), Dida Tuyura ranch (Boran breed) and Chefe Bante local markets (Harar breed) and $\mathrm{Su}$ lulta local market (HF-Crossbred) and transported to Haramaya University using

Table 1. Experimental design of the study.

\begin{tabular}{cccccc}
\hline \multirow{2}{*}{ Age } & \multicolumn{5}{c}{ Breeds } \\
\cline { 2 - 5 } & Borane & Arsi & Harar & HF-cross & \\
\hline $2-3$ yrs & 3 & 3 & 3 & 3 & 12 \\
$4-5$ yrs & 3 & 3 & 3 & 3 & 12 \\
Total & 6 & 6 & 6 & 6 & 24 \\
\hline
\end{tabular}


appropriate truck. The age of the animals was estimated using the dentition method as suggested by [22] [23].

They were quarantined for two weeks being vaccinated against blackleg disease and also dewormed by injecting with Ivermectin against internal and external parasites. After quarantine, each animal was kept in an individual pen and acclimatized for two weeks. The experiment lasted for 90 days.

\subsection{Experimental Feed and Chemical Analysis}

The experimental diet consists of roughage; natural grass hay, wheat straw and concentrate; maize grain, noug (gucia abysica) cake, wheat bran, limestone, salt, ruminant premix, and were analyzed for chemical composition at Haramaya university animal nutrition laboratory.

For chemical analysis 100 grams of samples of feeds were dried at $65^{\circ} \mathrm{C}$ for $48 \mathrm{hr}$. Then dried samples were then ground (1 $\mathrm{mm}$ screen) and stored for subsequent analyses of dry matter (DM), crude protein (CP), ash, neutral detergent fire (NDF) and acid detergent fire (ADF). DM, N and total ash were determined according to the official methods of [24] and NDF and ADF according to [25]. Dry matter content of the feed was determined by drying the samples in an oven at $105^{\circ} \mathrm{C}$ overnight while ash content was determined by burning the samples at $550^{\circ} \mathrm{C}$ for $5 \mathrm{~h}$ in a muff furnace. Nitrogen $(\mathrm{N})$ were determined by Kjeldahl method $(\mathrm{CP}=\mathrm{N} \times 6.25)$. The chemical composition of each dietary components is indicated in Table 2.

\subsection{Feed Formulation and Feed Intake Measurement}

The diet were formulated aiming to meet the maintenance requirements and to provide a weight gain of up to $1 \mathrm{~kg}$ per day as suggested by [26] for beef fattening center in Ethiopia. The roughage (60\% of total ration) component were natural grass hay (55\% of roughage) and wheat straw ( $45 \%$ of roughage); the concentrate (40\% of total ration) consisted of $34.78 \%$ wheat bran, $27.8 \%$ Noug cake, $33.14 \%$ maize grain, $1.7 \%$ limestone and $1.7 \%$ salt and $0.88 \%$ ruminant premix. It was formulated to contain $\mathrm{CP}$ and energy to meet the optimum recommendation of feedlot.

Table 2. Chemical composition of experimental feed ingredients.

\begin{tabular}{ccccccc}
\hline \multirow{2}{*}{ Feed type } & \multicolumn{7}{c}{ \% of items on DM } \\
\cline { 2 - 7 } & DM & Ash & CP & NDF & ADF & ADL \\
\hline Maize grain & 87.35 & 1.80 & 10.06 & 42.68 & 6.64 & 3.79 \\
Nuge (gucia abysica) cake & 90.46 & 8.48 & 45.74 & 42.91 & 27.94 & 10.07 \\
Wheat brane & 88.81 & 5.24 & 17.19 & 54.44 & 9.92 & 4.22 \\
Total mixed ration & 89.81 & 9.99 & 21.69 & 51.28 & 14.54 & 6.93 \\
Grass hay & 89.29 & 8.59 & 5.83 & 77.05 & 44.14 & 8.41 \\
Wheat straw & 94.49 & 5.94 & 3.14 & 80.64 & 45.32 & 6.14 \\
\hline
\end{tabular}

$\mathrm{DM}=$ dry matte, $\mathrm{CP}=$ Crude protein, $\mathrm{NDF}=$ neutral detergent fiber, $\mathrm{ADF}=$ acid detergent fiber, $\mathrm{ADL}=$ acid detergent lignin. 
Three percent of their body weight per day for total mixed ration was given in two equal meals at 8:00AM in the morning and 3:00PM in afternoon of the day and the amount were adjusted based on body weight once per every week. Clean water was available all the time. The weight of concentrate and roughage offered and refused were recorded daily to derive feed intake.

\subsection{Feed Conversion Efficiency}

Feed conversion efficiency (FCE) were calculated for each animal as proportion of weight gain to DM intake

$$
\mathrm{FCE}=\frac{\text { Weight gain }(\mathrm{kg})}{\text { DM Intake }(\mathrm{kg})}
$$

\subsection{Evaluation of Daily Weight Gain and Linear Measurements}

Animals were weighed once every week before morning feeding. Initial weight (IW) and final weight (FW) were recorded for different feeding periods.

$$
\mathrm{ADG}=\frac{\text { Final body weight }(\mathrm{Kg})-\text { Initial body weight }(\mathrm{kg})}{n \text { day }}
$$

where; ADG $=$ Average daily gain, $n=$ number of days, $n=90$

Body linear measurements such as total top line (the total length of the animal taken from front of the pool to back of the rump), neck length (the distance from front of the pool to the middle dip in vertebrate between the shoulder blades), hip height (height of the cattle on the vertical line passing through the hips), heart girth (the thoracic circumference), flank circumference (the total distance around the animal taken at the hips), rump length (the distance taken from the hips to the pin bones), rump or pin bone width (the horizontal distance between the pin bones), shoulder width (the horizontal distance between shoulders) and chest depth (the distance taken with vertical caliper through the vertical transverse plane passing just to the rear of the point of the elbow) were taken immediately after acclimatization period and two days before slaughter.

\subsection{Body Condition Scoring}

Body condition scoring for each experimental animals $(n=24)$ were recorded once in every week following body weight measurement during experimental feeding based on a 9 scale scoring method, with 1 being severely emaciated and 9 extremely obese, using the method proposed by [27] and modified by [28] as briefly indicated in (Table 3 ) below. To avoid subjective biasness, an expert has scored the condition throughout the experimental periods.

\subsection{Economic Analysis}

At the end of the experiment, partial budget analysis was performed to evaluate the economic advantage of feeding the four breeds of intact bulls with total mixed ration. It was done by considering the variable cost of bull price, concentrates and roughage prices, labor, medication and estimated bull sell prices at the 
Table 3. Visual method for evaluating body condition in cattle.

\begin{tabular}{|c|c|c|c|c|c|c|c|}
\hline \multicolumn{8}{|c|}{ Physical Attribute } \\
\hline & BSC & Spine & Ribs & Hooks/pins & Tailhead & Brisket & Muscling \\
\hline \multirow{2}{*}{ Thin } & 1 & Visible & Visible & Visible & No fat & No fat & None/atrophy \\
\hline & 2 & Visible & Visible & Visible & No fat & No fat & None/atrophy \\
\hline \multirow{2}{*}{ Borderline } & 3 & Visible & Visible & Visible & No fat & No fat & None \\
\hline & 4 & Slightly visibl & Foreribs visible & Visible & No fat & No fat & Full \\
\hline \multirow{2}{*}{ Optimum condition } & 5 & Not visible & Not visible & Visible & No fat & No fat & Full \\
\hline & 6 & Not visible & Not visible & Visible & Some fat & Some fat & Full \\
\hline \multirow{3}{*}{ Over conditioned } & 7 & Not visible & Not visible & Slightly visible & Some fat & Fat & Full \\
\hline & 8 & Not visible & Not visible & Not visible & Abundant fat & Abundant fat & Full \\
\hline & 9 & Not visible & Not visible & Not visible & Extremely fat & Extremely fat & Full \\
\hline
\end{tabular}

BCS = body condition score.

end of the experiment. At the end of experimental feeding, four experienced animal dealers were estimate the sell price of each experimental animals and the average price determined by the dealers was used as the selling price of individual bull. The difference in sell and purchase price was considered as total return (TR) in the analysis.

$$
\mathrm{TR}=\text { sell price }- \text { purchase price }
$$

The cost of feed was computed by multiplying the actual DM intake of feed for whole feeding period 90 days with the purchase price of the feed. The total cost associated with each animal during the experimental period were added and the total variable cost (TVC) were calculated for each animal. Net return (NR), was calculated by subtracting TVC from TR as follows.

$$
\mathrm{NR}=\mathrm{TR}-\mathrm{TVC}
$$

\subsection{Statistical Analysis}

The data were analyzed using General Linear Model (GLM) procedure of Statistical Analysis System [29] version 9.4. Simple linear regression was used for the determination of the most suitable model in the prediction of the live weight change using various body measurements change as continuous variables and simple regression was also used for change in body weight and body condition score to establish regression equations. The model included the main effects of age and breed to determine the influence of the main effects on all dependent variables considered. The difference among treatment means was tested using Tukeys' test at 0.05 level of significance.

The models used for the analysis were:

\section{Model I}

To evaluate effects of ages and breeds on weight gains and FCE

$$
Y_{i j k}=\mu+A_{i}+B_{j}+(A * B)_{i j}+e_{i j k}
$$


where

$Y_{i j k}=$ Response variable

$\mu=$ Overall mean

$A_{i}=$ age effect $(i=2$ level $)$

$B_{j}=$ breed effect $(j=4$ level $)$

$A{ }^{\star} B=$ interaction effect of age and breed

$e_{i j k}=$ random error

\section{Model II}

To calculate Relationships between change in body weight and change in BCS, linear body measurement (Total topline, Neck length, Flank circumference, Heart girth, Rump width).

$$
Y_{i}=\alpha+\beta X+\varepsilon
$$

where,

$Y_{i}=$ dependent variable (Live weight change)

$\alpha=$ intercept

$X=$ independent variable (BCS change, Total topline, Neck length, Flank circumference, Heart girth, Rump width change)

$\beta=$ regression slopes of (BCS change, Total topline, Neck length, Flank circumference, Heart girth, Rump width change)

$$
\varepsilon=\text { Residual. }
$$

\section{Results and Discussion}

\subsection{Bodyweight Change, Average Daily Weight Gain, Body Condition Score and Feed Conversion Efficiency}

Average initial and final live weights and daily weight gain of bulls from the four breeds under two age groups are summarized in Table 4. The significant difference in final and initial body weight of bulls from the four breeds and their respective two age categories cannot be explained as the bulls were different in their initial body weight at the start of the experiment. However, animals in higher age groups attain higher $(\mathrm{P}<0.001)$ body weight records in both initial and final body weight. This is in agreement with the previous finding by [30]. There was no statistically significant difference in average daily weight gain of the four breeds grouped to two age categories. However, the average daily weight gain in the current study ranges from 0.49 to $0.71 \mathrm{~kg}$ with an overall ADWG of $0.63 \mathrm{~kg}$. The average body weight gain in the present study was in line with the finding by Bedhane and Dadi (2016) who reported ADG $0.63 \mathrm{~kg}$ for Ethiopian Borana breeds with an estimated age of 4 years old.

The attained results in this study for Borana bulls were higher than the report of [7] which reported the daily body weight gain of the same breed about $0.44 \mathrm{~kg}$ in low input management system. The current result also showed the higher value of ADWG than the finding of [16] who reported $0.49 \mathrm{~kg}$ for 2 years old Borana bulls under natural grazing management. In addition, lower values of ADG were also reported by [32] which was a $0.51 \mathrm{~kg}$ for Ethiopian Highland 
Table 4. Effect of breeds and age on body weight, average daily weight gain $(\mathrm{kg})$ and feed conversion efficiency.

\begin{tabular}{|c|c|c|c|c|c|}
\hline \multirow{3}{*}{ Category } & \multirow{3}{*}{$\mathbf{N}$} & \multicolumn{2}{|c|}{ Body weight } & \multirow{2}{*}{ ADWG } & \multirow{2}{*}{ FCE } \\
\hline & & IBW & FBW & & \\
\hline & & Mean \pm SE & Mean \pm SE & Mean \pm SE & Mean \pm SE \\
\hline \multicolumn{6}{|l|}{ Breeds } \\
\hline Arsi & 6 & $130.83 \pm 5.71$ & $170.33 \pm 8.31$ & $0.49 \pm 0.03$ & $0.11 \pm 0.01$ \\
\hline Borana & 6 & $153.0 \pm 8.91$ & $209.5 \pm 14.69$ & $0.71 \pm 0.15$ & $0.13 \pm 0.02$ \\
\hline Cross & 6 & $162.16 \pm 10.18$ & $206.33 \pm 10.38$ & $0.65 \pm 0.09$ & $0.12 \pm 0.01$ \\
\hline Harar & 6 & $125.83 \pm 9.03$ & $179.83 \pm 7.60$ & $0.68 \pm 0.06$ & $0.15 \pm 0.02$ \\
\hline P-val & & Ns & Ns & Ns & NS \\
\hline \multicolumn{6}{|c|}{ Age } \\
\hline $2-3$ years & 12 & $126.83 \pm 6.02^{\mathrm{b}}$ & $171 \pm 5.94^{\mathrm{b}}$ & $0.57 \pm 0.05$ & $0.13 \pm 0.01$ \\
\hline 4 - 5 years & 12 & $159.0 \pm 8.78^{\mathrm{a}}$ & $211.5 \pm 10.73^{\mathrm{a}}$ & $0.67 \pm 0.08$ & $0.12 \pm 0.01$ \\
\hline \multicolumn{2}{|c|}{ P-Value } & $* *$ & $* * *$ & NS & NS \\
\hline Overall & 24 & $141.45 \pm 5.83$ & $191.5 \pm 7.31$ & $0.63 \pm 0.05$ & $0.12 \pm 0.01$ \\
\hline \multicolumn{2}{|c|}{ Breed * Age } & NS & NS & & NS \\
\hline
\end{tabular}

Means followed by different superscript letters within column are significantly different, $\mathrm{NS}=\mathrm{P}>0.05,{ }^{* *}=\mathrm{P}<0.001,{ }^{* *}=\mathrm{P}<0.01 ;^{*}=\mathrm{P}<0.05, \mathrm{FCE}=$ Feed conversion efficiency, IBW = initial body weight, FBW = final body weight, $\mathrm{ADWG}=$ average daily weight gain, $\mathrm{SE}=$ standard error of mean, $\mathrm{N}=$ sample number, $\mathrm{kg}=$ kilo gram.

Zebu (Bos indicus) oxen at age between 7 to 8 years that was fed on teff straw with concentrate supplement and [33] and $0.47 \mathrm{~kg}$ for Ogaden bulls grazing native pasture supplemented with agro-industrial by-products mix and hay at a ratio of 25:75 as compared to current study result, [18] for Ethiopian Borana breeds with an estimated age of 2 to 6 years old ranged $0.49 \mathrm{~kg}$ to $0.65 \mathrm{~kg}$ ADWG. However, almost comparable finding was reported by [17] who reported that two years old Borana bulls attained an ADWG of 0.77 to $0.8 \mathrm{~kg}$.

The average daily weight gain for the HF-Crossbred bulls in this study was lower than reports by [8] which was $0.87 \mathrm{~kg}$ for Horro-Friesian crossbred bulls in the age from 2 to 3 years; [34] which was $0.88 \mathrm{~kg}$ for crosses between Borana bulls and Friesian dam as well as $0.98 \mathrm{~kg}$ for a cross between Barca sire with Friesian dam at Holota research center. However, higher than the report by [31] who reported 0.54 kg ADWG for crossbreds at Bakko research center.

The ADWG of Afar bulls supplemented with different levels of concentrate under improved feeding management were between 0.54 and $0.62 \mathrm{~kg}$ [35]. This is in agreement with the value of Harar bulls in the current study. Moreover, [36] reported comparable ADG 0.44 to $0.57 \mathrm{~kg}$ for Arsi bulls. In contrast to the current finding [21] reported that Hararghe highland bulls feeding different concentrate feeds revealed a higher ADG of 1.21 to $1.33 \mathrm{~kg}$.

The feed conversion efficiency of the experimental bulls in this study was not 
significantly different $(\mathrm{P}>0.05)$ between breed, age as well as the interaction between breed and age. This is in line with the finding of [37] who revealed the absence of a significant difference between Fogera and Adet breed bulls. [20] also reported insignificant $(\mathrm{P}>0.05)$ differences among Borana and Arsi breed bulls. Similarly, [8] reported that feed conversion efficiency was higher for the lower age group but the differences were not significant $(P>0.05)$ for Horro-Friesian crossbred bulls. The overall mean value obtained in this study was comparable with the feed conversion efficiency of Fogera (0.10) oxen reported by [37] but higher than the value for Adet (0.09) oxen. Whereas higher values were reported by [20] for Boran (0.14) and Arsi (0.13).

The pattern of body condition score of three indigenous breeds and HF crossbred bulls for the two age categories were presented in Table 5 . The mean body condition score was the highest $(\mathrm{P}<0.05)$ for Arsi bulls compared to FH Crossbred while Harar and Borana bulls show intermediate body condition scores obtained during the start of experimental feeding. This variation might be due to the difference in animal management at their respective source before experimental feeding. HF crossbred bulls scored lower $(\mathrm{P}<0.01)$ body condition compared to all Borana, Harar and Arsi bulls in the final period of feeding.

Meanwhile, body condition score is an excellent indicator of the nutritional status of the animals and is an indirect reflection of the body reserve, the highest body condition score obtained for Arsi bulls, as well as the higher BCS change in Borana and Harar bulls, reveals that these animals were in a better nutritional

Table 5. Effect of breed and age on body condition scoring during the experimental feeding period.

\begin{tabular}{|c|c|c|c|c|c|c|c|}
\hline \multirow{3}{*}{ Category } & \multirow{3}{*}{$\mathbf{N}$} & \multicolumn{2}{|c|}{ Body condition scoring } & \multirow{2}{*}{ P-value } & \multicolumn{2}{|c|}{ Changes } & \multirow{2}{*}{$\begin{array}{c}\text { Change BW/BCS } \\
(\mathrm{kg})\end{array}$} \\
\hline & & Initial BCS & Final BCS & & BCS & BW (kg) & \\
\hline & & Mean \pm SE & Mean \pm SE & & Mean \pm SE & Mean \pm SE & Mean \pm SE \\
\hline \multicolumn{8}{|l|}{ Breeds } \\
\hline Borana & 6 & $3.79 \pm 0.19^{\mathrm{ab}}$ & $6.58 \pm 0.41^{\mathrm{a}}$ & & $2.78 \pm 0.40^{\mathrm{a}}$ & $56.5 \pm 12.71$ & $20.3 \pm 1.51^{\mathrm{b}}$ \\
\hline Arsi & 6 & $4.34 \pm 0.31^{\mathrm{a}}$ & $6.25 \pm 0.28^{\mathrm{a}}$ & & $1.91 \pm 0.34^{\mathrm{b}}$ & $39.5 \pm 3.01$ & $20.61 \pm 2.18^{\mathrm{ab}}$ \\
\hline Harar & 6 & $3.9 \pm 0.35^{\mathrm{ab}}$ & $6.50 \pm 0.18^{\mathrm{a}}$ & & $2.57 \pm 0.31^{\mathrm{a}}$ & $54 \pm 5.03$ & $22.42 \pm 2.17^{\mathrm{ab}}$ \\
\hline Crossbred & 6 & $3.08 \pm 0.26^{\mathrm{b}}$ & $4.66 \pm 0.42^{\mathrm{b}}$ & & $1.59 \pm 0.19^{\mathrm{b}}$ & $44.33 \pm 5.70$ & $27.78 \pm 1.73^{\mathrm{a}}$ \\
\hline P-val & & * & ** & & * & Ns & ** \\
\hline \multicolumn{8}{|l|}{ Age group } \\
\hline 2 - 3 years & 12 & $3.77 \pm 0.18$ & $5.87 \pm 0.25$ & & $2.10 \pm 0.21$ & $44.66 \pm 4.11$ & $21.93 \pm 1.44$ \\
\hline $4-5$ years & 12 & $3.87 \pm 0.20$ & $6.12 \pm 0.25$ & & $1.95 \pm 0.21$ & $47.75 \pm 2.79$ & $23.63 \pm 1.66$ \\
\hline \multicolumn{2}{|c|}{ P-value } & NS & NS & & NS & NS & Ns \\
\hline \multicolumn{2}{|l|}{ Overall } & $3.79 \pm 0.15^{\mathrm{b}}$ & $5.99 \pm 0.18^{\mathrm{a}}$ & $* *$ & $2.05 \pm 0.20$ & $48.08 \pm 3.78$ & $22.78 \pm 1.09$ \\
\hline \multicolumn{2}{|l|}{ Breed * Age } & * & NS & & NS & NS & Ns \\
\hline
\end{tabular}

Mean values under the same category that bear different superscript letters are significantly different, NS $=\mathrm{P}>0.05, * * *=\mathrm{P}<$ $0.001{ }^{* *}=\mathrm{P}<0.01{ }^{*}=\mathrm{P}<0.05, \mathrm{~N}=$ sample number, $\mathrm{BCS}=$ body condition score, $\mathrm{kg}=$ kilo gram, $\mathrm{SE}=$ standard error of mean. 
status and had better body reserve at the initial score and BCS change respectively. Therefore, change in body condition score is an indirect estimation of live body weight change. This is confirmed by several scholars in their works [32] [38] [39].

The estimated body weight change based on the change in body weight to change in BCS ratio was significantly $(\mathrm{P}<0.01)$ influenced by breeds as shown in Table 5. This result indicates that change of one condition score was significantly higher $(\mathrm{P}<0.01)$ for HF-crossbred bulls $(27.78 \mathrm{~kg})$ than Borana bulls $(20.3 \mathrm{~kg})$ whereas intermediate values $22.42 \mathrm{~kg}$ and $20.61 \mathrm{~kg}$ were recorded for Harar and Arsi bulls respectively. The higher body weight change per one condition score change for HF-Crossbred bull obtained in the current finding might be due to the heavier body size of HF-crossbred bulls than other local cattle bulls of similar age. Therefore, fattening HF-crossbred bulls was advantageous in beef production improvement.

The two age groups are not different in the initial BCS. Similarly, the BCS of the bull was the same under the two-age group during final feeding periods. The same holds true for change in BCS and BW change. On the other hand, there was a significant breed by age interaction effect on the initial body condition score of the four breeds. i.e., the difference in initial BCS between the four breed bulls depends on the age in which they are grouped. The Arsi bulls score higher body condition in the lower age group than the higher age group. However, the reverse was true in the Borana, Harar and HF crossbred (Figure 1).

The relationship between BW change and BCS change was presented in (Table 6). The relationship between BCS change and BW change was statically significant $(\mathrm{P}<0.01)$ in all factors. Bodyweight change and body condition score change were positively and strongly correlated in the breeds of Arsi, Borana, Harar and HF-crossbred bulls. The maximum correlation coefficient $(r=0.97)$

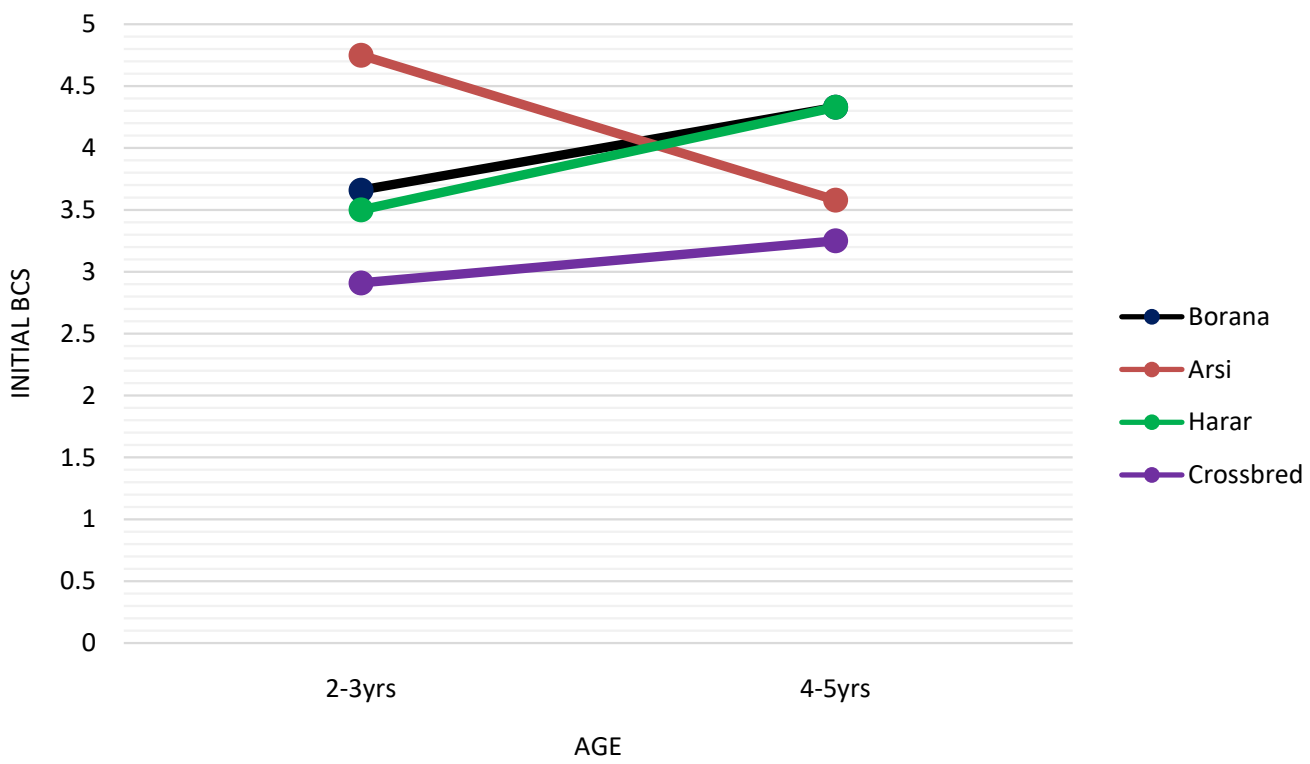

Figure 1. Breed by age interaction effect on initial body condition score. 
Table 6. Pearson correlation coefficient between body weight change and body condition score change.

\begin{tabular}{cccc}
\hline & & & BCS change \\
\hline Breeds & Arsi & BW change & $0.93^{* *}$ \\
& Borana & BW change & $0.97^{\star * *}$ \\
& HF-crossbred & BW change & $0.88^{\star}$ \\
& Harar & BW change & $0.96^{* *}$ \\
\hline Age & $2-3$ years & BW change & $0.89^{* * *}$ \\
& $4-5$ years & BW change & $0.70^{\star}$ \\
\hline Overall & & BW change & $0.80^{* * *}$ \\
\hline
\end{tabular}

$\mathrm{BW}=$ body weight, $\mathrm{BCS}=$ body condition score, ${ }^{* *}=\mathrm{P}<0.001,{ }^{* *}=\mathrm{P}<0.01$; $^{*}=\mathrm{P}<$ 0.05 .

for Borana and minimum correlation coefficient $(r=0.88)$ for HF-crossbred bulls were observed. Indicating a high level of association between body weight and body condition score changes. Similarly, there was a strong, positive and significant $(\mathrm{P}<0.01)$ correlation between $\mathrm{BW}$ and $\mathrm{BCS}$ change in the age categories of $2-3$ years, $4-5$ years and overall bulls. This is corroborated by the previous work that confirms that there were strong relationship between BCS and BW change in cattle [40] [41].

The regression equation predicting live weight change per body condition change for the two-age group and the entire experimental bulls were presented in Table 7. Accordingly, it means that change of one condition score is equivalent to 22.66, 20.87, 22.65 and $28.66 \mathrm{~kg}$ body weight in Arsi, Borana, Harar and HF-crossbred bulls respectively. When these experimental bulls were arranged in two age categories one body condition score change in $2-3$ years and $4-5$ years old bulls represent 23.65 and $26.53 \mathrm{~kg}$ bodyweight change, respectively. The average change of one condition score for all experimental bulls was equivalent to $25.99 \mathrm{~kg}$ body weight. Comparable with the current finding [42] reported one condition score was equivalent to $26 \mathrm{~kg}$ in males for Sudan cattle. The value of BW associated with the unit of BCS change in the current study was lower than previous report by [39] who reported a change of $31 \mathrm{~kg} \mathrm{BW}$ for every unit change in BCS for Holstein-Friesian cattle in New Zealand, [43] also reported the relationship between BW change and BCS in Holstein cows was 84.6 $\mathrm{kg} / \mathrm{BCS}$. However, the value of $25.99 \mathrm{~kg}$ from the present study agrees well with the range of 21 to $35 \mathrm{~kg} \mathrm{BW}$ per unit BCS in Holstein-Friesian cattle reported by [44]. [45] reported higher values for the regression 32 to $47 \mathrm{~kg} / \mathrm{BCS}$. Differences between studies in the relationship between BCS and BW change were due to BW is affected by breed, age sex and statistical models used [39]. Bodyweight values obtained as per change in one unit of body condition score was increasing 
Table 7. Relationship between live weight change and body condition change.

\begin{tabular}{cccccc}
\hline Category & & Models & $\mathbf{R}^{2}$ & MSE & P-value \\
\hline Breeds & Arsi & $Y=11.84 X+10.82$ & 0.87 & 2.80 & $* *$ \\
& Borana & $Y=16.5 X+4.37$ & 0.95 & 2.68 & $* * *$ \\
& Harar & $Y=16.18 X+6.47$ & 0.93 & 3.42 & $* *$ \\
& HF-crossbred & $Y=26.84 X+1.82$ & 0.78 & 7.25 & $*$ \\
\hline \multirow{2}{*}{ Age } & 2 - 3 years & $Y=14.06 X+9.19$ & 0.79 & 6.70 & $* * *$ \\
& $4-5$ years & $Y=13.57 X+12.96$ & 0.49 & 3.68 & $* *$ \\
\hline \multirow{2}{*}{ Overall } & & $Y=15.97 X+10.02$ & 0.56 & 12.54 & $* * *$ \\
\hline
\end{tabular}

Where, $Y=$ body weight change $(\mathrm{kg}), X=$ change in body condition score, $\mathrm{R}^{2}=$ coefficient of determination, $\mathrm{MSE}=$ mean square error, ${ }^{* *}=\mathrm{P}<0.001,{ }^{* *}=\mathrm{P}<0.01{ }^{*}=\mathrm{P}<$ 0.05 .

as the age of animals increasing. This is in agreement with earlier findings [32] [39].

Body condition scores of experimental bulls were improved over the feeding period where bulls in the final period of feeding had the higher $(\mathrm{P}<0.01)$ body condition score than initial BCS. This is corroborated by the works that confirm body condition scores were improved over the feeding period [8] [33].

\subsection{Correlation between Change in Body Weight and Linear Measurement}

Pearson's correlation coefficient $(r)$ between body weight change and linear body measurement change was presented in Table 8 . In both age categories and overall measurement, all of the changes in linear body measurements have a positive association with changes in body weight. Highly significant association were found between body weight change and total topline $(r=0.94, \mathrm{P}<0.0001)$, heart girth $(r=0.85, \mathrm{P}<0.0001)$, chest depth $(r=0.88, \mathrm{P}<0.0001)$ and flunk circumference $(r=0.81, \mathrm{P}<0.01)$ change in the younger age category. There was a highly significant and positive correlation between BW change and total topline change $(r=0.80, \mathrm{P}<0.01)$ and $(r=0.89, \mathrm{P}<0.0001)$ in the second age category and overall, respectively. Whereas change in neck length $(r=0.72, \mathrm{P}<0.05)$ and $(r=0.57, \mathrm{P}<0.05)$ moderately influence body weight change in the first $(2-$ 3 years) and second age group ( $4-5$ years) respectively. Change in heart girth $(r$ $=0.68, \mathrm{P}<0.05)$, flank circumference $(r=0.69, \mathrm{P}<0.05)$ and shoulder width $(r$ $=0.69, \mathrm{P}<0.05)$ has significant positive association with $\mathrm{BW}$ change in the second age group. Considering the overall experimental bulls in the relationship also shows a significant correlation between change in body weight and some of the linear body measurements. Likewise, the highest relationship was found between body weight change and change in total topline $(r=0.89, \mathrm{P}<0.0001)$, change in Heart girth $(r=0.75, \mathrm{P}<0.0001)$, change in flank circumference $(r=$ $0.73, \mathrm{P}<0.0001)$. Moreover, there was a moderately significant correlation between BW change and change in shoulder width $(r=0.56, \mathrm{P}<0.05)$ and chest 
Table 8. Correlation coefficient between change in body weight and linear body measurements.

\begin{tabular}{|c|c|c|c|c|c|c|c|c|c|}
\hline \multirow{2}{*}{ Age group } & \multicolumn{9}{|c|}{ Change in linear bogy measurement } \\
\hline & TLC & NLC & HLC & HCC & FCC & RLC & RWC & SWC & $\mathrm{CDC}$ \\
\hline rs BWC & 0.9 & $0.72^{\star}$ & & 0 . & $0.81^{\star \star}$ & $0.16^{\mathrm{ns}}$ & 0.9 & $0.46^{\mathrm{ns}}$ & \\
\hline $4-5$ yrs BWC & $0.80^{* *}$ & $0.57^{\star}$ & $0.29^{\text {ns }}$ & $0.68^{\star}$ & $0.69^{*}$ & $0.11^{\mathrm{ns}}$ & $0.95^{\star * *}$ & $0.69^{*}$ & $0.45^{\mathrm{ns}}$ \\
\hline Overall BWC & $0.89^{* * *}$ & $0.64^{* * *}$ & $0.29^{\text {ns }}$ & $0.75^{\star * *}$ & $0.73^{\star * *}$ & $0.16^{\mathrm{ns}}$ & $0.96^{* * *}$ & $0.56^{*}$ & $0.55^{\star *}$ \\
\hline
\end{tabular}

BWC $=$ Body weight change, yrs $=$ years, TLC $=$ Total topline change, NLC $=$ Neck length change, $\mathrm{HLC}=$ Hip length change, $\mathrm{HGC}=$ Heart girth change, FCC = Flank circumference change, $\mathrm{RLC}=$ Rump length change, $\mathrm{RWC}=\mathrm{Rump}$ width change, $\mathrm{SWC}=$ Shoulder width change, $\mathrm{CDC}=$ Chest depth change, $\mathrm{Ns}=$ not significance ${ }^{*}=(0.05)$ significance, ${ }^{* *}=(0.001)$ significance level.

depth $(r=0.55, \mathrm{P}<0.05)$. Change in ramp width was significantly correlated with BW change. However, there was no significant correlation between body weight change and change in hip length and rump length in both age groups as well as overall experimental bulls. Meaning that they did not significantly affect the change in body weight, so they were not more important in the prediction of live body weight change of the animal because of weak association with body weight change. This study is in agreement with some of the previous works by [46] that reported as correlation coefficients within age groups confirm the influence of these parameters on the relationships between live body weight and linear body measurements. [47] also suggest that the best estimations of body weight from linear body measurements should be developed from those that showed a strong correlation. Generally, as the result of correlation showed a change in total topline, neck length, heart girth, flank circumference, rump width and chest depth was the most important than other linear body measurement change for both age categories to estimate body weight change per unit change of linear measurement during fattening.

The prediction equations to estimate body weight change per unit change of linear body measurements were presented in Table 9. Individual linear body measurement parameters were used to establish the most appropriate models predicting the live body weight change of bulls during the fattening period. The different age categories as well as overall bulls were analyzed separately.

In the first age category regression model reveals that about $91 \%$ of the change in BW was influenced by a change in total topline and the remaining $9 \%$ was influenced by other factors outside the model such as cattle condition when measured and weighed, measurements method, the accuracy of measuring instruments and others. According to the Model, increasing $1 \mathrm{~cm}$ of the total topline of bulls was equivalent to increasing $8.21 \mathrm{~kg}$ of BW. Whereas change in $1 \mathrm{~cm}$ of total topline represents $9.6 \mathrm{~kg}$ and $8.0 \mathrm{~kg} \mathrm{BW}$ change in the second age group and when overall experimental bulls considered in the model respectively. In accordance with the present study, [48] observed the highest $\mathrm{R}^{2}$ value when body length alone was included in the regression model in 2 - 3 year Sahiwal male cattle. 
Table 9. Regression equations predicting live weight change $(\mathrm{Kg})$ from linear measurement change $(\mathrm{cm})$.

\begin{tabular}{|c|c|c|c|c|}
\hline Age group & Regression models & $\mathbf{R}^{2}$ & RMSE & P-value \\
\hline \multirow{6}{*}{$2-3 \mathrm{yrs}$} & $Y=8.12 \mathrm{TL}+1.99$ & 0.91 & 4.17 & $<0.0001$ \\
\hline & $Y=16.94 \mathrm{NL}+17.83$ & 0.52 & 9.85 & 0.0047 \\
\hline & $Y=4.83 \mathrm{HG}+15.87$ & 0.81 & 6.11 & $<0.0001$ \\
\hline & $Y=4.88 \mathrm{FC}+6.19$ & 0.79 & 7.12 & $<0.0001$ \\
\hline & $Y=21.03 \mathrm{RW}+14.42$ & 0.93 & 3.60 & $<0.0001$ \\
\hline & $Y=2.35 \mathrm{CD}+12.33$ & 0.90 & 4.49 & $<0.0001$ \\
\hline \multirow{6}{*}{$4-5 \mathrm{yrs}$} & $Y=9.60 \mathrm{TL}+2.12$ & 0.95 & 2.01 & $<0.0001$ \\
\hline & $Y=8.24 \mathrm{NL}+35.55$ & 0.33 & 8.29 & 0.0495 \\
\hline & $Y=3.27 \mathrm{HG}+26.46$ & 0.68 & 5.41 & 0.0005 \\
\hline & $Y=3.18 \mathrm{FC}+21.31$ & 0.77 & 4.61 & 0.0001 \\
\hline & $Y=19.37 \mathrm{RW}+15.45$ & 0.91 & 2.79 & $<0.0001$ \\
\hline & $Y=3.20 \mathrm{CD}+18.70$ & 0.51 & 6.77 & 0.0054 \\
\hline \multirow{6}{*}{ Overall } & $Y=8.00 \mathrm{TL}+6.20$ & 0.82 & 4.97 & $<0.0001$ \\
\hline & $Y=12.01 \mathrm{NL}+27.81$ & 0.38 & 9.41 & 0.0007 \\
\hline & $Y=4.13 \mathrm{HG}+20.49$ & 0.76 & 5.88 & $<0.0001$ \\
\hline & $Y=4.02 \mathrm{FC}+13.48$ & 0.77 & 5.69 & $<0.0001$ \\
\hline & $Y=20.16 \mathrm{RW}+14.90$ & 0.92 & 3.21 & $<0.0001$ \\
\hline & $Y=2.75 \mathrm{CD}+20.31$ & 0.71 & 6.43 & $<0.0001$ \\
\hline
\end{tabular}

RMSE $=$ Root mean square error, $\mathrm{R}^{2}=$ coefficient of determination, $\mathrm{TL}=$ Total topline, $\mathrm{FC}=$ Flank circumference, $\mathrm{RW}=$ Rump width, NL = Neck length, HG = Heart girth, $\mathrm{CD}$ $=$ Chest depth, $\mathrm{Kg}=$ kilo gram .

The variation in live body weight was also explained by the change in neck length, in this regression model, increment in $1 \mathrm{~cm}$ neck length represent 16.96 $\mathrm{kg}$ for bulls under 2 - 3 years age, $8.24 \mathrm{~kg}$ for $4-5$ years age and $12.01 \mathrm{~kg}$ in overall experiment. However, a maximum $\mathrm{R}^{2}$ value of 0.52 and a minimum $\mathrm{R}^{2}$ value of 0.33 were observed in the $2-3$ years and $4-5$ years age group respectively.

The coefficient of determination $\left(\mathrm{R}^{2}\right)$ value in simple linear regression using HG as the independent variable in both age groups was included in the high category $\left(0.68<\mathrm{R}^{2}<0.81\right)$. In line with the present finding, [49] reported the highest $\mathrm{R}^{2}$ value when the heart girth alone included in the regression models of HF crossbred 2 - 4 years, [48] also observed the highest $\mathrm{R}^{2}$ value when the heart girth alone included into the regression models in 2 - 3 Years Sahiwal female cattle. similarly, high category of $\mathrm{R}^{2}$ value $\left(0.61<\mathrm{R}^{2}<0.80\right)$ in regression models were reported in some breeds cattle of Abyssinian 0.65, Holstein Friesian 0.61, Ongole 0.79, crossbred dairy 0.67 and 0.73 for Lagune [50] [51] [52] [53] [54]. According to the Model, increasing $1 \mathrm{~cm}$ of HG was followed by increasing 4.83 
$\mathrm{kg}, 3.27 \mathrm{~kg}$ and $4.13 \mathrm{~kg}$ of BW for 2 - 3 year, 4 - 5 years and overall estimation respectively. In line with the current finding [52] reported change in $1 \mathrm{~cm} \mathrm{HG}$ was equivalent to $4.55 \mathrm{~kg}$ for bull and $3.26 \mathrm{~kg}$ of BW for a heifer. [50] also estimated a $1 \mathrm{~cm}$ change in heart girth would result in a weight change of 3.4 to 4.7 $\mathrm{kg}$ for Ethiopian highland oxen. [55] reported a $1 \mathrm{~cm}$ change in heart girth would result in a weight change of $3.37 \mathrm{~kg}$ for Bos indicus cattle in Kenya.

Change in flank circumference in all age categories indicates that about 77\% to $79 \%$ influenced BW change. One unit change in flank circumference was equivalent to 3.18 to $4.88 \mathrm{~kg}$ of BW in the current finding. $1 \mathrm{~cm}$ change in chest depth was also equivalent to $2.35 \mathrm{~kg}$ BW change in bulls under 2 - 3 years, $3.2 \mathrm{~kg}$ for 4 5 years and $2.75 \mathrm{~kg}$ BW change in overall estimation.

The higher $\mathrm{R}^{2}$ value and smaller RMSE attained using a single predictor in each age categories showed that the linear body measurements used as independent variables were good estimators of body weight. Generally, rump width was the most determinant linear body measurement variables in establishing a regression model in predicting BW change per unit of rump width change during fattening in all age categories.

\subsection{Economics of Fattening}

The partial budget analysis for the experimental feeding was reported in Table 10 which involved the evaluation of overall profitability. The economic analysis shows the highest $(\mathrm{P}<0.001)$ net benefit obtained from Borana bulls with a net return of 7380.47 ETB per head followed by Harar bulls, Arsi and HF Crossbred with a net profit of 5406.86, 5193.29 and 3384.98 ETB per head respectively. The

Table 10. Partial budget analysis of fattening different breeds of bulls fed similar total mixed ration.

\begin{tabular}{|c|c|c|c|c|c|c|c|c|}
\hline \multirow{2}{*}{ Category } & \multicolumn{8}{|c|}{ Economic parameters (Mean) (ETB/head) } \\
\hline & Purchase price & Feed cost & Medication cost & Labor cost & Sell price & TVC & TR & NR \\
\hline \multicolumn{9}{|l|}{ Breeds } \\
\hline Arsi & $5966.66^{\mathrm{b}}$ & 3343.04 & 80.33 & 250 & $14,833.33^{\mathrm{b}}$ & 3673.37 & $8866.66^{\mathrm{b}}$ & $5193.29^{\mathrm{b}}$ \\
\hline Borana & $7166.66^{\mathrm{b}}$ & 3989.25 & 46.94 & 250 & $18,833.33^{\mathrm{a}}$ & 4286.19 & $11,666.66^{\mathrm{a}}$ & $7380.47^{\mathrm{a}}$ \\
\hline Crossbred & $10,383.33^{\mathrm{a}}$ & 4036.51 & 111.83 & 250 & $18,166.66^{\mathrm{a}}$ & 4398.35 & $7783.33^{\mathrm{b}}$ & $3384.98^{\mathrm{b}}$ \\
\hline Harar & $7233.33^{\mathrm{b}}$ & 3396.14 & 47 & 250 & $16,333.33^{\mathrm{ab}}$ & 3693.14 & $9100^{\mathrm{b}}$ & $5406.86^{\mathrm{ab}}$ \\
\hline $\mathrm{P}$-value & $* * *$ & Ns & Ns & Ns & $* *$ & Ns & $* *$ & $* *$ \\
\hline \multicolumn{9}{|l|}{ Age } \\
\hline $2-3$ yrs & $6558.33^{\mathrm{b}}$ & $339.37^{\mathrm{b}}$ & 87.72 & 250 & $15125^{\mathrm{b}}$ & $3647.09^{\mathrm{b}}$ & $8566.66^{\mathrm{b}}$ & 4919.57 \\
\hline $4-5 y r s$ & $8816.66^{\mathrm{a}}$ & $4073.10^{\mathrm{a}}$ & 55.33 & 250 & $18,958.33^{\mathrm{a}}$ & $4378.43^{\mathrm{a}}$ & $10,141.66^{\mathrm{a}}$ & 5763.23 \\
\hline $\mathrm{P}$-value & $* * *$ & $* *$ & Ns & Ns & $* * *$ & $* *$ & * & Ns \\
\hline Overall & 7687.5 & 3691.23 & 71.52 & 250 & $17,041.66$ & 4012.76 & 9354.16 & 5341.40 \\
\hline
\end{tabular}

Mean values under the same category that bear different superscript letters are significantly different. ETB = Ethiopian birr, TVC $=$ Total variable cost, $\mathrm{TR}=$ Total return, $\mathrm{NR}=$ Net return, $\mathrm{ns}=\mathrm{P}>0.05,{ }^{* *}=\mathrm{P}<0.001,{ }^{* *}=\mathrm{P}<0.01{ }^{*}=\mathrm{P}<0.05, \mathrm{SE}=$ standard $^{*}$ error of mean. 
variation of net benefit among different breeds was mainly similar to their trend in weight gain difference among breeds. BCS and physical appearance of individual bulls also have a direct influence on the final sell price of each bull. Similar to this result, Adebabay et al. (2013) revealed that the net benefit of Fogera old oxen increased with increasing weight gain that resulted from the increased quantity of supplementation and final selling practice is based on body condition. According to the current result, feeding 3\% of body weight of total mixed ration was highly $(\mathrm{P}<0.01)$ profitable for Borana bulls which may be affected by total weight gain, physical appearance and body condition score. HF-crossbred bull was economically less $(\mathrm{P}<0.01)$ profitable compared with other breed bulls but statistically similar net profit was obtained from Arsi bulls. This indicates that HF-crossbred bull was less profitable under a limited feeding system because of their feed consumption is high as compared with other indigenous zebu bulls. This is concomitant with the report by [56] revealed that farmers around Holota agricultural research center were not even willing to use the crossbred cows, because of high feed consumption and difficulties to handle the animals.

Even though it is obvious from this result that the bulls in both age groups are statistically similar in net profit, one can go for the older groups which gives higher net return.

Generally, feeding 3\% of body weight of total mixed ration for 90 days was economically profitable providing an overall mean of 5341.40 ETB per head of bulls. However, further investigation on fattening HF-crossbred bulls under different levels of total mixed ration offering was recommended to evaluate economic profitability based on their weight gain and condition score performance.

\section{Conclusion and Recommendation}

From the result, it was concluded that the average daily weight gain of the four breeds range from 0.49 to $0.71 \mathrm{~kg}$. Change in body weight and body condition score was positively and strongly correlated in all breeds and age groups. Fattening HF-crossbred bulls was advantageous in beef production because of higher body weight change per one condition score change. Changes in linear body measurements have a positive association with changes in body weight. Moreover, rump width was the most determinant linear body measurement variable in establishing a regression model predicting BW change per unit of change in linear body measurement variables during fattening in all age categories. Feeding $3 \%$ of body weight of total mixed ration for 90 days was economically profitable in all experimental bull with the higher net return from Borana bulls. However, HF-Crossbred bulls need further investigation under different levels of offering total mixed ration to evaluate their potential for economic profitability.

\section{Acknowledgements}

Many of the research findings highlighted in this article were funded in whole or part by the United States Agency for International Development (USAID) Bu- 
reau for Food Security under Agreement \# AID-OAA-L-15-00003 as part of Feed the Future Innovation Lab for Livestock Systems. Any opinions, findings, conclusions, or recommendations expressed here are those of the authors alone. Furthermore, the authors would like to acknowledge the Ministry of Science and Higher Education of Ethiopia and Oda Bultum University for the partial support of the research activities and payment of salary of the research during the study.

I wormly thanks the Research Square for giving me a preprint of this manuscript.

\section{Availability of Data and Materials}

The datasets during and/or analysed during the current study available from the corresponding author on reasonable request.

\section{Funding}

This research was financialy funded by the United States Agency for International Development (USAID) Bureau for Food Security under Agreement \# AID-OAA-L-15-00003 as part of Feed the Future Innovation Lab for Livestock Systems. As well as Oda bultum University and Ministiry of Science and higher education are Co-funders.

\section{Author's Contribution}

Each author has made substantial contributions to the concept of the whole research.

\section{Conflicts of Interest}

The authors declared that there is no conflict of interest between authors and organizations regarding this paper.

\section{References}

[1] CSA (Central Statistical Agency) (2017) Federal Democratic Republic of Ethiopia. Livestock and Livestock Characteristics (Private Peasant Holdings).

[2] FAO (2007) FAO/WFP Crop and Food Supply Assessment Mission to Ethiopia. http://www.fao.org/giews

[3] DAGRIS (2011) Domestic Animal Genetic Resource Information System (DAGRIS). International Livestock Research Institute, Addis Ababa.

[4] FAO (Food and Agriculture Organization) (2018) Livestock Production Systems Spotlight. Cattle Sectors in Ethiopia. Africa Sustainable Livestock 2050, No. 2050, 9.

[5] Abera, H., Kebede, M., et al. (2008) On Farm Demonstration and Popularization of Backyard Oxen Fattening Technologies in Dano Districts, Western Oromia. Proceedings of the 16th Annual Conference of the Ethiopian Society of Animal Production (ESAP), Addis Ababa, 8-10 October 2008.

[6] Dinku, A. (2019) Assessment of Constraints and Opportunities in Small-Scale Beef Cattle Fattening Business: Evidence from the West Hararghe Zone of Ethiopia. International Journal of Veterinary Science and Research, 5, 58-68. 
https://doi.org/10.17352/ijvsr.000042

[7] Haile, A., Joshi, B.K., Ayalew, W., Tegegne, A. and Singh, A. (2009) Genetic Evaluation of Ethiopian Boran Cattle and Their Crosses with Holstein Friesian in Central Ethiopia: Milk Production Traits. Animal, 3, 486-493.

https://doi.org/10.1017/S1751731108003868

[8] Merera, C. and Galmessa, U. (2013) Fattening Performances of Culled Dairy Bulls to Boost Benefits of Dairy Farmers in Western Oromia, Ethiopia. International Journal of Livestock Production, 4, 161-164. https://doi.org/10.5897/IJLP2013.0170

[9] Mummed, Y.Y. (2015) Beef Carcass Quality, Yield and Causes of Condemnations in Ethiopia. PhD Dessertation, Pretoria University, Pretoria.

[10] Mummed, Y.Y. and Webb, E.C. (2015) Carcass Quality Audit a Strategy to Improve Beef Sector in Ethiopia. African Journal of Agricultural Research, 10, 2731-2737. https://doi.org/10.5897/AJAR2015.9524

[11] Mummed, Y.Y. and Webb, E.C. (2014) Ethiopian Beef Carcass Characteristics. African Journal of Agricultural Research, 9, 3766-3775.

[12] Mengistu, A., Kebede, G., Feyissa, F. and Assefa, G. (2017) Review on Major Feed Resources in Ethiopia: Conditions, Challenges and Opportunities. The Academic Research Journal of Agricultural Science and Research, 5, 176-185.

[13] Fikru, S. (2015) Assessment of Cattle Fattening and Marketing Practice in Harshin District of Somali Regional State, Ethiopia. Advances in Dairy Research, 3, Article ID: 1000137. https://doi.org/10.4172/2329-888X.1000137

[14] Ayalew, T., Duguma, B. and Tolemariam, T. (2013) Traditional Cattle Fattening and Live Animal Marketing System in Different Agro-Ecologies of Ilu Aba Bora Zone, Oromia, Ethiopia. Global Veterinaria, 10, 620-625.

[15] Negassa, A., Rashid, S. and Gebremedhin, B. (2011) Livestock Production and Marketing. Development Strategy and Governance Division, International Food Policy Research Institute-Ethiopia Strategy Support Program II, Ethiopi. ESSP II Working Paper 26. https://www.ifpri.org

[16] Negash, M., Lemma, T., Feyera, T., Dadi, H., Woldu, T. and Tesfay, A.L. (2008) Comparison of Body Weight Gain Performance and Carcass Characteristics of the Two Ethiopian Cattle Breeds under Natural Pasture Grazing Management. Livestock Research for Rural Development, 20.

http://www.lrrd.org/lrrd20/8/nega20117.htm

[17] Girma, D., Mieso, G., Tesfaye, A., Arse, G., Frehowit, M., Ashebir, W. and Aman, G. (2015) Effect of Different Feeds Option on Growth Response and Carcass Characteristic of Two Years Aged Borana Bulls for Export Market Weight Gain at Adami Tulu Agricultural Research Center. Basic Research Journal of Agricultural Science and Review, 4, 139-145.

[18] Bedhane, M. and Dadi, H. (2016) Growth and Slaughter Characteristics of Ethiopian Boran Breed Bull. International Journal of Livestock Research, 6, 41-50. https://doi.org/10.5455/ijlr.20150215090156

[19] O’Donovan, P.B., Taylor, M.S., WoleGebriel, A., Gebrewolde, A., Gala, E.S.E. and Tadesse, A. (1980) Fattening Trials with Zebu and Crossbred Cattle at Bako, Wollega. Ethiopian Journal of Agricultural Sciences.

[20] Tolla, N., Mirkena, T. and Yiemegnuhal, A. (2002) Comparison of the Efficiency of Compensatory Growth of Borana and Arsi Cattle in Ethiopia. Ethiopian Journal of Animal Production, 2, 11-23.

[21] Gebremariam, T.T. (2019) Feedlot Performance and Carcass Yield of Hararghe 
Highland (Bos Indicus) Bulls Using Different Concentrate Feeds. Acta Scientiarum. Animal Sciences, 41, 1-7. https://doi.org/10.4025/actascianimsci.v41i1.42557

[22] Hammond Jr., J., Mason, I.L. and Robinson, T.J. (1971) Hammond's Farm Animals (4th Edition). Experimental Agriculture, 8, 179-180.

[23] MLA (Meat and Livestock Australia) (2011) Tropical Beef Production Manual. Module 3 Cattle Husbandry, Welfare and Management. Meat and Livestock Australia, North Sydney.

[24] AOAC (1990) AOAC Official Methods of Analysis. 15th Edition, Volume 1, Association of Official Agricultural Chemists, Washington DC, 136-138.

[25] van Soest, P.J., Robertson, J.B. and Lewis, B.A. (1991) Polysaccharides in Relation to Animal Nutrition. Journal of Dairy Science, 74, 3583-3597. https://doi.org/10.3168/jds.S0022-0302(91)78551-2

[26] David, H. (2006) Feeding to Produce Export Quality Ethiopian Beef Requirements and Recommendations.

[27] Herd, D.B. and Sprott, L.R. (1986) Body Condition, Nutrition and Reproduction of Beef Cattle. Texas Agricultural Experiment Station Bulletin.

[28] Farney, J.K., Blasi, D.A., Johnson, S., Reinhardt, C., Tarpof, A.J., Waggoner, J. and Weaber, R. (2016) Guide to Body Condition Scoring Beef Cows and Bulls. KSTATE Research and Extension, 1-8.

[29] SAS (2018) Statistical Analysis Software. Users' Guide Statistics Version 9.4. SAS Institute Inc., Cary, 1-37.

[30] Bassa, Z., Wolde, S., Alemu, T., Yilma, M., Terra, A., Zeleke, B. and Gemiyu, D. (2016) Evaluation of Locally Available Energy Source Feeds on Fattening Performance of Local Oxen and Carcass Analysis in Wolaita, Southern. Hydrology: Current Research, 7, 3-7. https://doi.org/10.4172/2157-7587.1000255

[31] O’Donovan, P.B.O., Gebrewolde, A., Kebede, B. and Galal, E.S.E. (1978) Fattening Studies with Cross-Bred (EuropeanXZebu) Bulls: 1. Performance on Diets of Native Hay and Concentrate. The Journal of Agricultural Science, 90, 425-429.

https://doi.org/10.1017/S0021859600055532

[32] Osuji, P.O. and Capper, B. (1992) Effect of Age on Fattening and Body Condition of Draught Oxen Fed Teff Straw (Eragrostis Teff) Based Diets. Tropical Animal Health and Production, 24, 103-108. https://doi.org/10.1007/BF02356953

[33] Mekasha, Y., Urge, M., Kurtu, M.Y. and Bayissa, M. (2011) Effect of Strategic Supplementation with Different Proportion of Agro-Industrial By-Products and Grass Hay on Body Weight Change and Carcass Characteristics of Tropical Ogaden Bulls (Bos Indicus) Grazing Native Pasture. African Journal of Agricultural Research, 6, 825-833.

[34] Teklebrhan, P.B.O., Gebrewolde, A., Kebede, B. and Galal, E.S.E. (1978) Fattening Studies with Cross-Bred (EuropeanXZebu) Bulls: 1. Performance on Diets of Native Hay and Concentrate. The Journal of Agricultural Science, 90, 425-429. https://doi.org/10.1017/S0021859600055532

[35] Aregawi, W.G., Philimon, T., Werkisa, C., Kidanie, D., Birhanu, M. and Workinesh, S. (2018) Effect of Improved Feeding Management on Body Weight Gain and Carcass Characteristics of Afar Bulls for Export Market. International Journal of Animal Science Research, 2, 1-5.

[36] Tolla, N., Mirkena, T. and Yimegnuhal, A. (2003) Effect of Feed Restriction on Compensatory Growth of Arsi (Bos Indicus) Bulls. Animal Feed Science and Technology, 103, 29-39. https://doi.org/10.1016/S0377-8401(02)00214-6 
[37] Kebede, A., Bitew, A., Bimrew, T., Yitayew, A., Denekew, Y., Ferede, Y. and Zele, G. (2013) Comparative Evaluation of the Fattening Performance of Fogera and Adet Old Oxen at Andassa Livestock Research Center, Ethiopia. International Journal of Pharmaceutical and Bio-Medical Science, 2, 66-75.

[38] Nicholson, M.J. and Sayers, A.R. (1987) Relationships between Body Weight, Condition Score and Heart Girth Changes in Boran Cattle. Tropical Animal Health and Production, 19, 115-120. https://doi.org/10.1007/BF02297329

[39] Berry, D.P., Macdonald, K.A., Penno, J.W. and Roche, J.R. (2006) Association between Body Condition Score and Live Weight in Pasture-Based Holstein-Friesian Dairy Cows. Journal of Dairy Research, 73, 487-491.

https://doi.org/10.1017/S0022029906002020

[40] Díaz-López, G., Salazar-Cuytun, R., Herrera, R.G., Piñeiro-Vázquez, A., CasanovaLugo, F. and Chay-Canul, A.J. (2017) Relationship between Body Weight and Body Condition Score with Energy Content in the Carcass of Pelibuey Ewes. Austral Journal of Veterinary Sciences, 49, 77-81. https://doi.org/10.4067/S0719-81322017000200077

[41] Evangelista, G.T., Lopes, J.F., Fornar, G.B., Oaigen, R.P., Gonçalves, T.L., De Oliveira, T.E., De Aguiar, L.K. and Barcellos, J.O.J. (2019) Key Factors Influencing the Sale of Bulls in Livestock Auctions. Revista Mexicana de Ciencias Pecuarias, 10, 610-622. https://doi.org/10.22319/rmcp.v10i3.4609

[42] Milla, A.P. and Mahjoub, M.M. (2013) Estimation of Live Body Weight from Heart Girth, Body Length and Condition Score in Nilotic Cattle Southern Sudan. Agricultural Technology Transfer Society Magazine, 1, 15-19.

[43] Fox, D.G., Van Amburgh, M.E. and Tylutki, T.P. (1999) Predicting Requirements for Growth, Maturity, and Body Reserves in Dairy Cattle. Journal of Dairy Science, 82, 1968-1977. https://doi.org/10.3168/jds.S0022-0302(99)75433-0

[44] Enevoldsen, C. and Kristensen, T. (1997) Estimation of Body Weight from Body Size Measurements and Body Condition Scores in Dairy Cows. Journal of Dairy Science, 80, 1988-1995. https://doi.org/10.3168/jds.S0022-0302(97)76142-3

[45] Jaurena, G., Moorby, J.M., Fisher, W.J. and Cantet, R. (2005) Association of Body Weight, Loin Longissimus Dorsi and Backfat with Body Condition Score in Dry and Lactating Holstein Dairy Cows. Animal Science, 80, 219-223.

https://doi.org/10.1079/ASC41750219

[46] Vanvanhossou, S.F.U., Diogo, R.V.C. and Dossa, L.H. (2018) Estimation of Live Bodyweight from Linear Body Measurements and Body Condition Score in the West African Savannah Shorthorn Cattle in North-West Benin. Cogent Food \& Agriculture, 4, 1-12. https://doi.org/10.1080/23311932.2018.1549767

[47] Tsegaye, D., Belay, B. and Haile, A. (2013) Linear Body Measurements as Predictor of Body Weight in Hararghe Highland Goats under Farmers Environment: Ethiopia. Global Veterinaria, 11, 649-656.

[48] Bhagat, V., Khune, V., Chourasia, S.K., Gendley, M.K. and Mukherjee, K. (2016) Linear Regression Equations for Estimation of Body Weights in Sahiwal Calves. Journal of Animal Research, 2, 161-163. https://doi.org/10.5958/2277-940X.2015.00187.4

[49] Ashwini, J.P., Sanjay, P., Amipara, G.J., et al. (2019) Prediction of Body Weight Based on Body Measurements of Yak. International Journal of Current Microbiology and Applied Sciences, 8, 1597-1611. https://doi.org/10.20546/ijcmas.2019.803.186

[50] Goe, M.R., Alldredge, J.R. and Light, D. (2001) Use of Heart Girth to Predict Body 
Weight of Working Oxen in the Ethiopian Highlands. Livestock Production Science, 69, 187-195. https://doi.org/10.1016/S0301-6226(00)00257-8

[51] Ozkaya, S. and Bozkurt, Y. (2009) The Accuracy of Prediction of Body Weight from Body Measurements in Beef Cattle. Archives Animal Breeding, 52, 371-377. https://doi.org/10.5194/aab-52-371-2009

[52] Putra, W.P.B. (2020) The Assessment of Body Weight of Sumba Ongole Cattle (Bos Indicus) by Body Measurements. Manas Journal of Agriculture Veterinary and Life Sciences, 9, 104-111.

[53] Lukuyu, M.N., Gibson, J.P., Savage, D.B., Duncan, A.J., Mujibi, F.D.N. and Okeyo, A.M. (2016) Use of Body Linear Measurements to Estimate Liveweight of Crossbred Dairy Cattle in Smallholder Farms in Kenya. SpringerPlus, 5, 63.

https://doi.org/10.1186/s40064-016-1698-3

[54] Comlan, A.B.G., Steve, A.J. and Ibrahim, A.T. (2017) Use of Body Measurements to Estimate Live Weight of Lagune Cattle in Use of Body Measurements to Estimate Live Weight of Lagune Cattle in Southern Benin. The Saudi Journal of Life Sciences, 2, 23-32.

[55] Odadi, W.O. (2018) Using Heart Girth to Estimate Live Weight of Heifers (Bos Indicus) in Pastoral Rangelands of Northern Kenya. Livestock Research for Rural Development, 30, 1-9.

[56] Gojam, Y., Tadesse, M., Effa, K. and Hunde, D. (2017) Performance of Crossbred Dairy Cows Suitable for Smallholder Production Systems at Holetta Agricultural Research Centre. Ethiopian Journal of Agricultural Sciences, 27, 121-131. 